Louisiana State University

LSU Digital Commons

Faculty Publications

Department of Chemistry

3-10-2016

\title{
Synthesis and in Vitro Studies of a Series of Carborane-Containing Boron Dipyrromethenes (BODIPYs)
}

\author{
Sunting Xuan \\ Louisiana State University \\ Ning Zhao \\ Louisiana State University \\ Zehua Zhou \\ Louisiana State University \\ Frank R. Fronczek \\ Louisiana State University \\ M. Graça H. Vicente \\ Louisiana State University
}

Follow this and additional works at: https://digitalcommons.Isu.edu/chemistry_pubs

\section{Recommended Citation}

Xuan, S., Zhao, N., Zhou, Z., Fronczek, F., \& Vicente, M. (2016). Synthesis and in Vitro Studies of a Series of Carborane-Containing Boron Dipyrromethenes (BODIPYs). Journal of Medicinal Chemistry, 59 (5), 2109-2117. https://doi.org/10.1021/acs.jmedchem.5b01783

This Article is brought to you for free and open access by the Department of Chemistry at LSU Digital Commons. It has been accepted for inclusion in Faculty Publications by an authorized administrator of LSU Digital Commons.

For more information, please contact ir@lsu.edu. 
Published in final edited form as:

J Med Chem. 2016 March 10; 59(5): 2109-2117. doi:10.1021/acs.jmedchem.5b01783.

\title{
Synthesis and in Vitro Studies of a Series of Carborane- Containing Boron Dipyrromethenes (BODIPYs)
}

\author{
Sunting Xuan, Ning Zhao, Zehua Zhou, Frank R. Fronczek, and M. Graça H. Vicente* \\ Department of Chemistry, Louisiana State University, Baton Rouge, Louisiana 70803, United \\ States
}

\begin{abstract}
A series of seven BODIPYs functionalized with ortho-carborane groups at the 8 (meso) or $3 / 5(a)$ position were synthesized and characterized by NMR, HRMS, HPLC, and in the cases of $\mathbf{2 b}$ and $\mathbf{5 b}$, by X-ray analysis. The BODIPYs exhibited low dark toxicity and phototoxicity toward human glioma T98G cells, and their cellular uptake varied significantly, with $\mathbf{5 b}$ accumulating the most and 7 the least. All BODIPYs localized mainly within the cell ER. The BODIPYs showed higher permeabilities than lucifer yellow across human hCMEC/D3 brain endothelial cell monolayers as the BBB model. Among this series, $1 \mathrm{~b}$ showed the highest BBB permeability $\left(P_{\mathrm{e}}=16.4 \times 10^{-5}\right.$ $\mathrm{cm} / \mathrm{s}$ ), probably as a result of its lower MW (366 Da) and favorable hydrophobicity ( $\log P=1.5$ ). The combination of low cytotoxicity, amphiphilicity, high boron content, high cellular uptake, and moderate $\mathrm{BBB}$ permeability renders these compounds promising boron delivery agents for the BNCT of brain tumors.
\end{abstract}

\section{Graphical Abstract}

\footnotetext{
"Corresponding Author: Phone: 225-578-7405. Fax: 225-578-3458. ; Email: vicente@1su.edu Notes

The authors declare no competing financial interest.

ASSOCIATED CONTENT

Supporting Information

The Supporting Information is available free of charge on the ACS Publications website at DOI: 10.1021/acs.jmedchem. 5b01783.

${ }^{1} \mathrm{H},{ }^{13} \mathrm{C}$, and ${ }^{11} \mathrm{~B}$ NMR spectra for all carboranyl-BODIPYs, HPLC traces and conditions, absorption and emission spectra, concentration-dependent dark and phototoxicity graphs, and microscopy images (PDF) Molecular formula strings (CSV)
} 


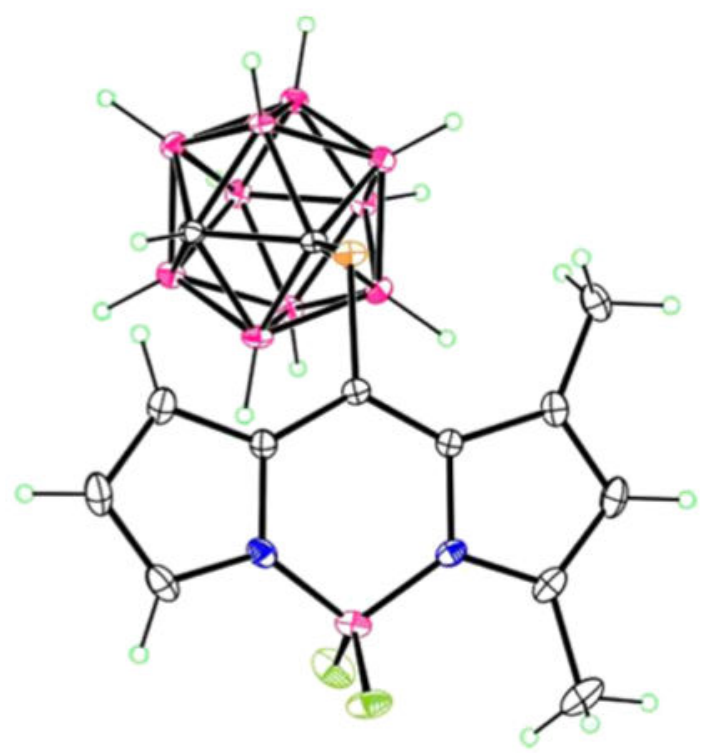

\section{INTRODUCTION}

Boron neutron capture therapy (BNCT) is a very promising binary anticancer methodology, especially for the treatment of brain tumors because it can selectively target and destroy malignant cells in the presence of healthy normal cells. ${ }^{1 \_3}$ BNCT involves the irradiation of nonradioactive ${ }^{10} \mathrm{~B}$-containing tumors with low-energy thermal neutrons, causing the excitation of ${ }^{10} \mathrm{~B}$ to ${ }^{11} \mathrm{~B}$, which rapidly produces cytotoxic high linear energy transfer (highLET) $a$ and ${ }^{7} \mathrm{Li}$ particles, $\gamma$ radiation, and about $2.4 \mathrm{MeV}$ of kinetic energy through a nuclear fission reaction. The generated high-LET particles have short path lengths of less than $10 \mu \mathrm{m}$ in tissue, therefore restricting the damage to ${ }^{10} \mathrm{~B}$-containing tumor cells. Furthermore, biologically abundant nuclei including ${ }^{12} \mathrm{C},{ }^{1} \mathrm{H}$, and ${ }^{14} \mathrm{~N}$ possess very small nuclear cross sections, thus posing little interference with the ${ }^{10} \mathrm{~B}(\mathrm{n}, a)^{7} \mathrm{Li}$ capture reaction. Another advantage of BNCT is that thermal and epithermal neutrons are able to penetrate deep into tissues to reach deep-seated tumors. However, a relatively high boron tumor concentration of at least $20 \mu \mathrm{g}{ }^{10} \mathrm{~B} / \mathrm{g}$ tumor is required for effective BNCT treatment, and this has driven recent research in the areas of boron drug development and delivery methodologies for BNCT.

BNCT has been applied for the treatment of high-grade brain tumors, such as glioblastoma multiforme (GBM), and other difficult-to-treat malignancies, including melanomas and recurrent head and neck cancers. ${ }^{3} 5$ One major challenge in the BNCT modality for brain tumors arises from the existence of the blood-brain barrier (BBB) that prevents most drugs from penetrating into the brain and from reaching the targeted tumor cells. ${ }^{6}{ }^{11}$ The BBB permeability of drugs has been shown to be related to the physicochemical properties of the drugs, including their lipophilic character, molecular weight (MW), size, polar surface area, charge, and extent of ionization. ${ }^{12 \_14}$ Among these, the two main characteristics in a small molecule that favor its crossing of the BBB by passive diffusion are (1) molecular weight under $500 \mathrm{Da}$ and (2) high lipophilic character, usually measured by the octanol-water 
partition coefficient, $\log P<5 .{ }^{6}{ }^{12 \_14}$ Although significant hydrophobicity is important for enhanced permeability across the BBB, BNCT drugs also need to be soluble in aqueous media to enable their systemic administration. ${ }^{2}$ Therefore, there is continued need to develop amphiphilic compounds as boron delivery drugs for BNCT of brain tumors, with appropriate balance between hydrophilicity and lipophilicity, as well as molecular weight of $<500 \mathrm{Da}$ for efficient BBB permeability and tumor cell uptake.

Two boron-containing drugs of low molecular weight have been extensively used in BNCT clinical trials: the sodium salt of the sulfhydryl boron hydride $\mathrm{Na}_{2} \mathrm{~B}_{12} \mathrm{H}_{11} \mathrm{SH}(\mathrm{BSH})$ and L-4-dihydroxyborylphenylalanine (BPA). ${ }^{3} 5$ Although BSH and BPA have demonstrated efficacy in BNCT clinical trials, they have very limited BBB permeability. ${ }^{10},{ }^{15}$ Other boronated compounds have been investigated as potential BNCT drugs, including amino acids, peptides, carbohydrates, nucleosides, liposomes, porphyrins, and monoclonal antibodies (mAbs). ${ }^{2}, 7$ Among these, particularly promising are mAbs due to their very high specificity for a tumor-associated epitope, and porphyrin derivatives due to their ability to transport large amounts of boron within cells. However, these BNCT agents have limited BBB crossing ability, mainly due to their large size, high molecular weight, and hydrophobicity. ${ }^{2}, 15$

We have recently investigated the BBB permeability of a series of carboranylporphyrins conjugated to polyamines, glucose, arginine, and an opioid peptide, ${ }^{16}$ but they all showed low permeabilities $\left(P_{\mathrm{e}}<3.3 \times 10^{-6} \mathrm{~cm} / \mathrm{s}\right)$ across hCMEC/D3 cell monolayers ${ }^{17} 19$ as the BBB model. On the other hand, amphiphilic boron dipyrromethene (BODIPY) compounds of low molecular weight could show enhanced permeability and promise as boron delivery drugs for BNCT. ${ }^{20}$ BODIPY dyes have attracted special interest in recent years due to their various applications in biological labeling, drug delivery, imaging, sensing, and theranostics. ${ }^{21 \_24}$ BODIPYs are strongly UV-vis absorbing and generally emit sharp fluorescence with high quantum yields, which can facilitate detection and quantification of tissue-localized boron in BNCT. BODIPYs have also shown negligible sensitivity toward solvent polarity and solution $\mathrm{pH}$, high permeability across cellular membranes, and relatively high stability under physiological conditions.

BODIPYs functionalized with carborane clusters have been prepared via Suzuki ${ }^{20}$ and Sonogashira ${ }^{25}$ cross-coupling reactions of the corresponding 2,6-diiodo-substituted compounds. Alternatively, carboranes can be introduced onto the BODIPY at the 3(5)and/or 8-positions through substitution reactions on the corresponding chlorinated derivatives. ${ }^{20},{ }^{26}, 27$ Herein we report the synthesis of a series of seven carboranyl-BODIPYs from the corresponding chloro-BODIPY derivatives, with molecular weights in the range 366-527 Da and $\log P$ in the range 1.5-2.7. The cytotoxicity and uptake of the BODIPYs in human glioma T98G cells, as well as their permeability across the BBB using hCMEC/D3 cells, were investigated and compared. 


\section{EXPERIMENTAL SECTION}

\section{Synthesis}

All the chemicals and reagents were purchased from Sigma-Aldrich and Fisher Scientific and used as received. 1-Mercapto-1,2-carborane was purchased from Katchem. Reactions were monitored by analytical thin-layer chromatography (TLC) performed on precoated plates (polyester-back, $60 \AA, 0.2 \mathrm{~mm}$, Sorbent Technologies). Purifications were conducted by column chromatography on silica gel (230-400 mesh, $60 \AA$, Sorbent Technologies) or preparative TLC plates (f254, VWR). ${ }^{1} \mathrm{H}$ and ${ }^{13} \mathrm{C}$ NMR spectra were obtained using a Bruker AV-400 NanoBay (400 MHz for ${ }^{1} \mathrm{H}$ NMR and $100 \mathrm{MHz}$ for ${ }^{13} \mathrm{C}$ NMR) and a Bruker AV-500 spectrometer (125 MHz for ${ }^{13} \mathrm{C}$ NMR) at room temperature. ${ }^{11} \mathrm{~B}$ NMR was obtained on a Bruker AV-400 III (128 MHz), using $\mathrm{BF}_{3} \cdot \mathrm{OEt}_{2}$ as reference. Chemical shifts $(\delta)$ are given in parts per million (ppm) in $\mathrm{CDCl}_{3}$ (7.27 ppm for ${ }^{1} \mathrm{H} \mathrm{NMR}, 77.0 \mathrm{ppm}$ for ${ }^{13} \mathrm{C} \mathrm{NMR}$ ); coupling constants $(J)$ are given in Hz. High resolution mass spectrometry (HRMS) spectra were obtained using a 6210 ESI-TOF mass spectrometer (Agilent Technologies). Normalphase HPLC was performed on a Dionex system including a P680 pump and UVD 340 detector connected to a Dynamax axial compression column packed with Rainin $60 \AA$ irregular silica gel. The flow rate of $1 \mathrm{~mL} / \mathrm{min}$ was used. For compound $\mathbf{1 b}$, a stepwise gradient of 50\% B (ethyl acetate) and 50\% A (hexane) in the first 3 min to $80 \% \mathrm{~B}$ and $20 \%$ A during the next $18 \mathrm{~min}$ to $50 \% \mathrm{~B}$ and $50 \% \mathrm{~A}$ for the next 6 min was used. For all other compounds, a stepwise gradient of $10 \% \mathrm{~B}$ and $90 \% \mathrm{~A}$ in the first 5 min to $70 \% \mathrm{~B}$ and $30 \%$ A during the next 10 min to $10 \% \mathrm{~B}$ and $90 \%$ A for the next 10 min was used. All compounds were of $\geq 95 \%$ purity, as determined by HPLC (see Supporting Information, Figures S17-S23). The commercially available LY standard is of $97 \%$ purity, as provided by Life Technologies. 4-(1-Methyl-1,2-carborane)-methylphenylboronic acid ${ }^{28}$ and BODIPYs $\mathbf{1 a},{ }^{29} \mathbf{3 a},{ }^{26} \mathbf{3 b},{ }^{20} \mathbf{6 a},{ }^{27}$ and $7^{27}$ were synthesized as previously reported.

\section{General Procedure for Synthesis of BODIPYs via Nucleophilic Substitution Reaction-The starting chloro-BODIPY $(0.05 \mathrm{mmol})$ was dissolved in $2 \mathrm{~mL}$ of THF. 1- Mercapto-1,2-carborane $(0.055 \mathrm{mmol})$ and $\mathrm{K}_{2} \mathrm{CO}_{3}(0.5 \mathrm{mmol})$ were added, and the final mixture was stirred at room temperature. TLC was used to monitor the reaction until completion ( $2-5 \mathrm{~h})$. The crude solid product was filtered and purified by column chromatography or preparative TLC using $\mathrm{CH}_{2} \mathrm{Cl}_{2} /$ hexanes or ethyl acetate/hexanes for elution.}

8-(1,2-Carboranyl-1-thio)-BODIPY 1b: $16.1 \mathrm{mg}(88 \%)$, mp 213-215 ${ }^{\circ} \mathrm{C} .{ }^{1} \mathrm{H}$ NMR $\left(\mathrm{CDCl}_{3}, 400 \mathrm{MHz}\right): \delta 8.01(2 \mathrm{H}, \mathrm{s}), 7.36(2 \mathrm{H}, \mathrm{s}), 6.64(2 \mathrm{H}, \mathrm{s}), 3.77(1 \mathrm{H}, \mathrm{s}), 1.8-3.5(10 \mathrm{H}$, br). ${ }^{13} \mathrm{C} \mathrm{NMR}\left(\mathrm{CDCl}_{3}, 100 \mathrm{~Hz}\right): \delta 148.6,139.4,133.3,132.2,120.4,72.2,65.0 .{ }^{11} \mathrm{~B}$ NMR $\left(\mathrm{CDCl}_{3}, 128 \mathrm{MHz}\right): \delta-0.08\left(1 \mathrm{~B}, \mathrm{t},{ }^{1} J_{(\mathrm{B}, \mathrm{F})}=27.8 \mathrm{~Hz}\right),-12.97$ to $-1.57(10 \mathrm{~B}, \mathrm{~m})$. HRMS (ESI-TOF) $\mathrm{m} / z$ calcd for $\mathrm{C}_{11} \mathrm{H}_{17} \mathrm{~B}_{11} \mathrm{~F}_{1} \mathrm{~N}_{2} \mathrm{~S}[\mathrm{M}-\mathrm{F}]^{+}$347.2199; found 347.2200.

8-(1,2-Carboranyl-1-thio)-1,3-dimethyl-BODIPY 2b: $18.7 \mathrm{mg}(95 \%), \mathrm{mp} 157-160{ }^{\circ} \mathrm{C} .{ }^{1} \mathrm{H}$ NMR $\left(\mathrm{CDCl}_{3}, 400 \mathrm{MHz}\right): \delta 7.71(1 \mathrm{H}, \mathrm{s}), 7.10(1 \mathrm{H}, \mathrm{s}), 6.49(1 \mathrm{H}, \mathrm{s}), 6.29(1 \mathrm{H}, \mathrm{s}) 3.79(1 \mathrm{H}$, s), $2.65(1 \mathrm{H}, \mathrm{s}), 2.55(1 \mathrm{H}, \mathrm{s}), 1.8-3.5(10 \mathrm{H}, \mathrm{br}) .{ }^{13} \mathrm{C} \mathrm{NMR}\left(\mathrm{CDCl}_{3}, 100 \mathrm{~Hz}\right): \delta 166.9,148.6$,

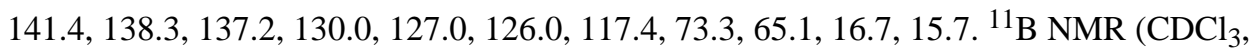


$128 \mathrm{MHz}): \delta 0.14\left(1 \mathrm{~B}, \mathrm{t},{ }^{1} J_{(\mathrm{B}, \mathrm{F})}=29.8 \mathrm{~Hz}\right),-12.97$ to $-1.60(10 \mathrm{~B}, \mathrm{~m})$. HRMS (ESI-TOF) $\mathrm{m} / z$ calcd for $\mathrm{C}_{13} \mathrm{H}_{22} \mathrm{~B}_{11} \mathrm{~F}_{2} \mathrm{~N}_{2} \mathrm{~S}[\mathrm{M}+\mathrm{H}]^{+}$395.2576; found 395.2566.

8-(1,2-Carboranyl-1-thio)-2-ethyl-1,3,6,7-tetramethyl-BODIPY 5b: $20.9 \mathrm{mg}$ (93\%), mp 198-200 ${ }^{\circ} \mathrm{C} .{ }^{1} \mathrm{H}$ NMR $\left(\mathrm{CDCl}_{3}, 400 \mathrm{MHz}\right): \delta 7.44(1 \mathrm{H}, \mathrm{s}), 3.70(2 \mathrm{H}, \mathrm{s}), 2.58(3 \mathrm{H}, \mathrm{s}), 2.44-$ 2.45 (8H, overlap, m), $2.02(3 \mathrm{H}, \mathrm{s}), 1.8-3.5(10 \mathrm{H}, \mathrm{br}), 1.05-1.09\left(3 \mathrm{H}, \mathrm{t},{ }^{3} J_{(\mathrm{H}, \mathrm{H})}=7.4\right.$ $\mathrm{Hz}) .{ }^{13} \mathrm{C} \mathrm{NMR}\left(\mathrm{CDCl}_{3}, 100 \mathrm{~Hz}\right): \delta 162.7,141.5,141.1,137.8,137.2,134.1,130.1,128.4$, 74.9, 64.1, 17.3, 14.5, 14.2, 14.0, 13.4, 10.2. ${ }^{11} \mathrm{~B}$ NMR ( $\left.\mathrm{CDCl}_{3}, 128 \mathrm{MHz}\right): \delta-0.06$ (1B, $\left.\mathrm{t},{ }^{1} J_{(\mathrm{B}, \mathrm{F})}=30.0 \mathrm{~Hz}\right),-11.89$ to $-1.64(10 \mathrm{~B}, \mathrm{~m})$. HRMS (ESI-TOF) $\mathrm{m} / z$ calcd for $\mathrm{C}_{17} \mathrm{H}_{30} \mathrm{~B}_{11} \mathrm{~F}_{2} \mathrm{~N}_{2} \mathrm{~S}[\mathrm{M}+\mathrm{H}]^{+}$451.3204; found 451.3195 .

8-(1,2-Carboranyl-1-thio)-3-chloro-2-ethyl-1,3,6,7-tetramethyl-BODIPY 6b: $17.9 \mathrm{mg}$ (74\%), mp 192-194 ${ }^{\circ} \mathrm{C} .{ }^{1} \mathrm{H}$ NMR $\left(\mathrm{CDCl}_{3}, 400 \mathrm{MHz}\right): \delta 3.69(1 \mathrm{H}, \mathrm{s}), 2.60(3 \mathrm{H}, \mathrm{s}), 2.44(8 \mathrm{H}$, overlap, m), $2.00(3 \mathrm{H}, \mathrm{s}), 1.8-3.5(10 \mathrm{H}, \mathrm{br}), 1.06-1.10\left(3 \mathrm{H}, \mathrm{t},{ }^{3} J_{(\mathrm{H}, \mathrm{H})}=7.6 \mathrm{~Hz}\right) .{ }^{13} \mathrm{C} \mathrm{NMR}$ $\left(\mathrm{CDCl}_{3}, 125 \mathrm{~Hz}\right): \delta 163.1,141.3,141.2,137.8,137.7,137.6,132.7,128.5,126.4,74.9,64.1$, 17.3, 14.8, 14.6, 14.1, 13.5, 9.1. ${ }^{11} \mathrm{~B}$ NMR $\left(\mathrm{CDCl}_{3}, 128 \mathrm{MHz}\right): \delta 0.08\left(1 \mathrm{~B}, \mathrm{t},{ }^{1} J_{(\mathrm{B}, \mathrm{F})}=30.0\right.$ $\mathrm{Hz}),-12.94$ to $-1.45(10 \mathrm{~B}, \mathrm{~m})$. HRMS (ESI-TOF) $\mathrm{m} / z$ calcd for $\mathrm{C}_{17} \mathrm{H}_{29} \mathrm{~B}_{11} \mathrm{ClF}_{2} \mathrm{~N}_{2} \mathrm{~S}[\mathrm{M}+$ $\mathrm{H}]^{+}$485.2818; found 485.2824 .

8-[4-(2-Methyl-1,2-carboranyl)methylphenyl]-BODIPY 4: BODIPY 1a (11.3 mg, 0.05 $\mathrm{mmol})$ was dissolved in toluene $(4 \mathrm{~mL}) .1 \mathrm{M} \mathrm{Na}_{2} \mathrm{CO}_{3}(\mathrm{aq})(1 \mathrm{~mL}), \mathrm{Pd}\left(\mathrm{PPh}_{3}\right)_{4}(5 \% \mathrm{~mol})$, and 4-(1-methyl-o-carborane)methylphenylboronic acid $(29.2 \mathrm{mg}, 0.1 \mathrm{mmol})$ were added, and the final mixture was refluxed overnight. The mixture was poured into water $(10 \mathrm{~mL})$ and extracted with dichloromethane $(10 \mathrm{~mL} \times 3)$. The organic layers were collected, washed with $\mathrm{H}_{2} \mathrm{O}$ and brine, and dried over anhydrous $\mathrm{Na}_{2} \mathrm{SO}_{4}$. The solvents were removed by rotary evaporation to give the crude products. The further purification was performed by column chromatography (ethyl acetate/hexanes as the eluent) to provide the titled product $(10.6 \mathrm{mg})$ in $45 \%$ yield; $\mathrm{mp} 195-197{ }^{\circ} \mathrm{C} .{ }^{1} \mathrm{H} \mathrm{NMR}\left(\mathrm{CDCl}_{3}, 400 \mathrm{MHz}\right): \delta 8.0(2 \mathrm{H}, \mathrm{s}), 7.56-$ $7.58(2 \mathrm{H}, \mathrm{m}), 7.37-7.39(2 \mathrm{H}, \mathrm{m}), 6.92(2 \mathrm{H}, \mathrm{s}), 6.58(2 \mathrm{H}, \mathrm{s}), 3.57(2 \mathrm{H}, \mathrm{s}), 2.22(3 \mathrm{H}, \mathrm{s}), 1.8-$ 3.5 (10h, br). ${ }^{13} \mathrm{C} \mathrm{NMR}\left(\mathrm{CDCl}_{3}, 100 \mathrm{~Hz}\right): \delta 146.4,144.5,137.7,134.9,133.6,131.5,130.7$, $130.4,118.7,75.0,40.9,23.8 .{ }^{11} \mathrm{~B} \mathrm{NMR}\left(\mathrm{CDCl}_{3}, 128 \mathrm{MHz}\right): \delta 0.18\left(1 \mathrm{~B}, \mathrm{t},{ }^{1} J_{(\mathrm{B}, \mathrm{F})}=28.6\right.$ $\mathrm{Hz}),-10.74$ to $-3.16(10 \mathrm{~B}, \mathrm{~m})$. HRMS (ESI-TOF) $\mathrm{m} / z$ calcd for $\mathrm{C}_{19} \mathrm{H}_{25} \mathrm{~B}_{11} \mathrm{FN}_{2}[\mathrm{M}-$ $\mathrm{F}]^{+}$419.3108; found 419.3111 .

\section{Spectroscopic Studies}

UV-visible and fluorescence spectra were collected on a PerkinElmer Lambda $35 \mathrm{UV} / \mathrm{vis}$ spectrometer and PerkinElmer LS 55 luminescence spectrometer at room temperature. Quartz cuvettes (10 mm path length) and spectroscopic grade solvents were used for both measurements. Optical density $(\varepsilon)$ was determined by using the solutions with absorbance at $\lambda_{\max }(0.5-1)$. Quantum yields were determined by using the dilute solutions with absorbance (0.04-0.06) at the particular excitation wavelength. Cresyl violet perchlorate ( 0.54 in methanol) and rhodamine $6 \mathrm{G}$ in ethanol (0.95) were used as external standards for the carboranyl BODIPYs $\mathbf{5 b}, \mathbf{6 b}$, and $\mathbf{1 b}-\mathbf{3 b}, \mathbf{4}, \mathbf{7}$, respectively. The relative fluorescence quantum yields $\left(\Phi_{\mathrm{f}}\right)$ were determined by calculations using the following equation, ${ }^{30}$ 


$$
\Phi_{\mathrm{X}}=\Phi_{\mathrm{R}}\left(F_{\mathrm{X}} / F_{\mathrm{R}}\right)\left(A_{\mathrm{R}} / A_{\mathrm{X}}\right)\left(n_{\mathrm{X}} / n_{\mathrm{R}}\right)^{2} \Phi_{\mathrm{R}}
$$

where $\Phi$ stands for fluorescence quantum yields, $n$ stands for refractive indexes, $F$ stands for the areas under the emission peaks, $A$ stands for absorbance at the particular excitation wavelength, and subscripts $\mathrm{X}$ and $\mathrm{R}$ refer to the tested and standard samples, respectively.

\section{Crystallography}

$\mathrm{X}$-ray data for $\mathbf{2 b}$ and $\mathbf{5 b}$ were collected at $90 \mathrm{~K}$ with Mo Karadiation $(\lambda=0.71073 \AA$ ) on a Bruker Kappa Apex-II DUO diffractometer. For BODIPY $2 \mathbf{b}, \mathrm{C}_{13} \mathrm{H}_{21} \mathrm{~B}_{11} \mathrm{~F}_{2} \mathrm{~N}_{2} \mathrm{~S}$, monoclinic space group $P 2_{1} / c, a=10.7729(5) \AA, b=15.7487(7) \AA, c=12.5738(6) \AA, \beta=104.222(2)^{\circ}$, $V=2067.88(17) \AA^{3}, Z=4,22855$ measured data. Final $R=0.040, \mathrm{Rw}=0.106$ for 264 refined parameters and 7883 independent reflections having $\theta_{\max }=33.2^{\circ}$. For BODIPY $\mathbf{5 b}$, $\mathrm{C}_{17} \mathrm{H}_{29} \mathrm{~B}_{11} \mathrm{~F}_{2} \mathrm{~N}_{2} \mathrm{~S}$, monoclinic space group $P 2_{1} / c, a=13.688(2) \AA b=12.1938(17) \AA, c=$ 15.488(2) $\AA, \beta=113.231(6)^{\circ}, V=2375.3(6) \AA^{3}, Z=4,47866$ measured data. Final $R=$ 0.040 , Rw $=0.110$ for 303 refined parameters and 8658 independent reflections having $\theta_{\max }$ $=32.6^{\circ}$. The CIFs have been deposited at the Cambridge Crystallographic Data Centre (CCDC 1426277-1426278).

\section{Octanol-Water Partition Coefficients}

The partition coefficients $(\log P)$ were measured by adapting a reported procedure. ${ }^{31} 1$ Octanol and Milli-Q water were mutually saturated, and the two phases were separated. A $64 \mu \mathrm{M}$ stock solution was prepared by dissolving the BODIPY into water-saturated 1octanol. Then $2 \mathrm{~mL}$ of the stock solution was added to $6 \mathrm{~mL}$ of Milli-Q water in a $15 \mathrm{~mL}$ volumetric tube and the mixture was intensively vortexed for $10 \mathrm{~min}$. After complete separation of the two phases, an aliquot from the 1-octanol layer was diluted with watersaturated 1-octanol and its absorbance was recorded with a Varian Cary 50 Bio UV-vis spectrophotometer with a $10 \mathrm{~mm}$ path length quartz cuvette. The $\log P$ values were calculated as follows:

$$
\log P=\log \left(\frac{A_{\text {oct }}}{A_{0}-A_{\text {oct }}} \frac{V_{\mathrm{W}}}{V_{\mathrm{O}}}\right)
$$

where $A_{0}$ and $A_{\text {oct }}$ are the absorbance of the compound in the water-saturated octanol before and after partitioning; $V_{\mathrm{w}}$ and $V_{\mathrm{O}}$ are the water and 1-octanol volumes, respectively.

\section{Cell Studies}

The T98G cell line used in this study was purchased from ATCC and cultured in ATCCformulated Eagle's minimum essential medium containing 10\% FBS and 1\% antibiotic (penicillin-streptomycin). The HEp2 cells were also purchased from ATCC and maintained in a 50:50 mixture of DMEM/AMEM supplemented with 5\% FBS and Primocin antibiotic. The hCMEC/D3 cells were obtained from Dr. Pierre-Olivier Couraud from Institut COCHIN in Paris (France). All other reagents were purchased from Life Technologies. 
5.1. Dark Cytotoxicity-A $32 \mathrm{mM}$ compound stock solution was prepared by dissolving the BODIPY in $100 \%$ DMSO. The stock solution was diluted into final working concentrations $(0,6.25,12.5,25,50$, and $100 \mu \mathrm{M})$. Human glioma T98G cells were plated at 15000 cells per well in a Costar 96-well plate (BD biosciences) and allowed to grow for 24 h. The cells were exposed to the working solutions of compounds up to $100 \mu \mathrm{M}$ and incubated overnight $\left(37{ }^{\circ} \mathrm{C}, 95 \%\right.$ humidity, $\left.5 \% \mathrm{CO}_{2}\right)$. The working solution was removed, and the cells were washed with $1 \times$ PBS. The medium containing $20 \%$ CellTiter Blue (Promega) was added and incubated for $4 \mathrm{~h}$. The viability of cells is measured by reading the fluorescence of the medium at 570/615 nm using a BMG FLUOstar Optima microplate reader. This fast, sensitive, and popular assay uses the indicator dye resazurin which is reduced to fluorescent resorufin in viable cells, while nonviable cells are not able to reduce resazurin or to generate a fluorescent signal. The fluorescence signal of the untreated cells was normalized to $100 \%$.

5.2. Phototoxicity-Human glioma $T 98 \mathrm{G}$ cells were prepared as described above. The cells were incubated with compound concentrations of 100, 50, 25, 12.5, 6.25, 3.125, and 0 $\mu \mathrm{M}$ for $24 \mathrm{~h}$. The loading medium was removed, and the cells were washed with $1 \times$ PBS buffer and then refilled with fresh media. The cells were exposed to a $600 \mathrm{~W}$ halogen lamp light source filtered with a water filter (transmits radiation $250-950 \mathrm{~nm}$ ) and a beam turning mirror with $200 \mathrm{~nm}$ to $30 \mu \mathrm{m}$ spectral range (Newport), for $20 \mathrm{~min}$. The total light dose was approximately $1.5 \mathrm{~J} / \mathrm{cm}^{2}$. After light exposure, the cells were returned to the incubator for 24 $\mathrm{h}$ and assayed for cell viability as described above.

5.3. Time-Dependent Cellular Uptake-Human T98G cells were prepared as described above. The cells were exposed to $10 \mu \mathrm{M}$ of each compound solution for $0,1,2,4,8$, and 24 $\mathrm{h}$. The loading medium was removed at the end of each incubation period, and the cells were washed with $1 \times$ PBS and solubilized by adding $0.25 \%$ Triton X-100 in $1 \times$ PBS. Standard curves using $10,5,2.5,1.25,0.625$, and $0.3125 \mu \mathrm{M}$ concentrations were obtained by diluting $400 \mu \mathrm{M}$ of each BODIPY solution with $0.25 \%$ Triton X-100 (Sigma-Aldrich) in $1 \times$ PBS. A cell standard curve was prepared using $10^{4}, 2 \times 10^{4}, 4 \times 10^{4}, 6 \times 10^{4}, 8 \times 10^{4}$, and $10^{5}$ cells per well. The cell number was quantified using a CyQuant cell proliferation assay (Life Technologies). The compound concentration in cells at each time period was determined using a BMG FLUOstar Optima microplate reader at $485 / 590 \mathrm{~nm}$. Cellular uptake is expressed in terms of compound concentration (nM) per cell.

5.4. Microscopy-Human HEp2 cells were incubated in a six-well plate (MatTek) and allowed to grow overnight. The cells were exposed to $10 \mu \mathrm{M}$ of each BODIPY and incubated for $6 \mathrm{~h}\left(37^{\circ} \mathrm{C}, 95 \%\right.$ humidity, $\left.5 \% \mathrm{CO}_{2}\right)$, followed by the addition of organelle tracers obtained from Invitrogen. The organelle tracers were used at the following concentrations: LysoSensor Green, $50 \mathrm{nM}$; MitoTracker Green, $250 \mathrm{nM}$; ER Tracker Blue/ White, $100 \mathrm{nM}$; and BODIPY FL C5 Ceramide, $50 \mathrm{nM}$. The cells were incubated with the BODIPY and tracers for 30 min and washed with PBS three times before imaging. The images were acquired using a Leica DMRXA2 upright microscope with a water immersion objective and DAPI, GFP, and Texas Red filter cubes (Chroma Technologies). 
5.5. hCMEC/D3 Cell Line (BBB Model)—The BBB permeabilities were determined following a published procedure. ${ }^{32,},{ }^{33}$ Specifically, the hCMEC/D3 cells were incubated in a six-well, $0.4 \mu \mathrm{m}$ porosity PET Transwell plate (Corning) for $48 \mathrm{~h}$, allowing the formation of a model brain capillary endothelial monolayer (checked by microscopy). EBM-2 medium containing $5 \% \mathrm{FBS}, 1 \%$ penicillin/streptomycin, hydrocortisone, ascorbic acid, chemically defined lipid concentrate (1/100), HEPES, and bFGF was used as the growth medium. The coated PET Transwell plates with and without endothelial cells were transferred into sixwell plates. The measurements were performed in triplicate for each compound, using three PET Transwell plates with cells and three without cells. The time points of the treatment were $0,10,25$, and $45 \mathrm{~min}$. At time 0 , a $0.5 \mathrm{~mL}$ sample of each BODIPY or standard lucifer yellow (LY) at $50 \mu \mathrm{M}$ concentration in transport buffer was added to the upper chamber (mimicking the blood), and $1.5 \mathrm{~mL}$ of transport buffer was added to the lower chamber (mimicking the BBB); see Figure S24 in the Supporting Information. The transport buffer was prepared by adding $5 \mathrm{~mL}$ of HEPES $(1 \mathrm{M})$ and $5 \mathrm{~mL}$ of sodium pyruvate $(100 \mu \mathrm{M})$ to $400 \mathrm{~mL}$ of HBSS. The plates were incubated at $37{ }^{\circ} \mathrm{C}, 95 \%$ humidity, and $5 \% \mathrm{CO}_{2}$. At time 10 and 25 min, each upper PET Transwell was transferred to the corresponding prepared sixwell plate containing $1.5 \mathrm{~mL}$ of transport buffer: the so-called " $25 \mathrm{~min}$ " first and then the "45 min". At each time point, solution in the lower chamber was added into a 96-well plate with $100 \mu \mathrm{L}$ for each well (five wells). The fluorescence intensity of the solution was measured by using a BMG FLUOstar plate reader at $485 / 590 \mathrm{~nm}$ and $425 / 538 \mathrm{~nm}$ (excitation/emission) for BODIPYs and LY, respectively, and the concentrations were determined from the corresponding standard curves. The calculations of permeability coefficients $\left(P_{\mathrm{e}}\right.$, in $\left.\mathrm{cm} / \mathrm{s}\right)$ were performed following the clearance principle as described in the equations below (eqs 1 and 2), where $X$ is the amount of sample in the lower chamber and $\mathrm{Cd}$ is the concentration of sample in the upper chamber at each time point. The total cleared volume at each time point is calculated by summing the incremental cleared volumes up to the given time point.

$$
\text { clearance }(\mathrm{mL})=X / \mathrm{Cd}
$$

The cleared volume is plotted vs time, and a linear fit is applied.

$$
P_{\mathrm{e}}(\mathrm{cm} / \mathrm{s})=\left(\frac{1}{\mathrm{PSt}}-\frac{1}{\mathrm{PSf}}\right) /(A \times 60)
$$

where PSt is the slope of the clearance curve for the culture, PSf is the slope of the clearance curve with the control Transwell plate without cells, and $A$ is the surface area of the PET Transwell plate. 


\section{RESULTS AND DISCUSSION}

\section{Synthesis and Characterization}

A series of seven carboranyl-BODIPYs $\mathbf{1 b}, \mathbf{2 b}, \mathbf{3 b},{ }^{20} \mathbf{4}, \mathbf{5 b}, \mathbf{6 b}$, and $\mathbf{7},{ }^{27}$ five of which are new, were synthesized as shown in Scheme 1. The key chloro-BODIPY starting materials were synthesized from the corresponding dipyrroketones, as previously reported. ${ }^{26,27,29}$ The ortho-carborane cluster was chosen as the boron source because of its high boron content, high hydrophobicity, high stability under physiologic conditions, and low toxicity. ${ }^{711} 8$ Chloro-BODIPYs 1a-3a and 5a were converted into their corresponding 8-carboranylthioBODIPYs by reaction with 1.1 equiv of 1 -mercapto- $o$-carborane in THF at room temperature, in yields ranging from $88 \%$ to $95 \%$. We have previously reported that 3,8 dichloro-BODIPY 6a undergoes highly regioselective substitutions at the 8-position in the presence of $\mathrm{N}$ - and O-centered nucleophiles. ${ }^{27}$ Using more reactive S-nucleophiles, the 8- vs 3 -substitution regioselectivity tends to decrease. However, due to the electron-withdrawing nature of the carborane cluster, BODIPY 6a reacted smoothly with 1.1 equiv of 1-mercapto$o$-carborane, affording $\mathbf{6 b}$ with high regioselectvity in $74 \%$ yield. On the other hand, BODIPY 7 was prepared from 6a via two successive regioselective reactions, a Stille crosscoupling at the 8-position using 1 equiv of tributylphenylstannane and $\mathrm{Pd}\left(\mathrm{PPh}_{3}\right)_{4}$, followed by substitution using an excess of 1-mercapto- $o$-carborane, as we have previously reported. $^{27}$ The Suzuki cross-coupling reaction of BODIPY 1a with 1.5 equiv of 4-(1methyl-o-carborane)-methylphenylboronic acid in toluene and in the presence of $\mathrm{Pd}\left(\mathrm{PPh}_{3}\right)_{4}$ and $1 \mathrm{M} \mathrm{Na}_{2} \mathrm{CO}_{3}(\mathrm{aq})$ produced BODIPY 4 in $45 \%$ isolated yield.

The structures of the new BODIPYs $\mathbf{1 b}, \mathbf{2 b}, \mathbf{5 b}, \mathbf{6 b}$, and $\mathbf{4}$ were confirmed by ${ }^{1} \mathrm{H},{ }^{13} \mathrm{C}$, and ${ }^{11} \mathrm{~B}$ NMR, HRMS and in the cases of $\mathbf{2 b}$ and $\mathbf{5 b}$ by X-ray crystallography (Figure 1). We have previously reported the X-ray structures of $\mathbf{3 b}{ }^{20}$ and $7 .{ }^{27}$ Crystals of BODIPYs $2 \mathbf{b}$ and $\mathbf{5 b}$ suitable for $\mathrm{X}$-ray analysis were obtained by slow diffusion of hexanes into chloroform (Figure 1). In $\mathbf{2 b}$, the B atom of the central $\mathrm{C}_{3} \mathrm{~N}_{2} \mathrm{~B}$ ring lies slightly $(0.214 \AA$ ) out of the plane of the other five atoms, which are fairly coplanar, having a mean deviation of $0.013 \AA$. The carborane lies on the bisector of this plane, with C-C-S-C torsion angle $93.9^{\circ}$. In $\mathbf{5 b}$, the central ring is slightly more planar, with the 8-C atom lying $0.098 \AA$ out of the $\mathrm{C}_{2} \mathrm{~N}_{2} \mathrm{~B}$ plane. The $\mathrm{S}$ atom lies $0.319 \AA$ out of this plane, and as in $\mathbf{2 b}$, the carborane lies on the bisector, with $\mathrm{C}-\mathrm{S}-\mathrm{C}-\mathrm{C}$ torsion angle of $94.1^{\circ}$. The ethyl group is also approximately perpendicular to the ring system, with $\mathrm{C}-\mathrm{C}-\mathrm{CH}_{2}-\mathrm{CH}_{3}$ torsion angle of $83.7^{\circ}$.

The spectroscopic properties of all BODIPYs in dichloromethane solution were investigated, and the results are summarized in Table 1 (see also Figures S32-S44 of the Supporting Information). The absorption spectra of all BODIPYs followed the Lambert-Beer law, indicative of no aggregation in this solvent at the concentrations tested. The introduction of an ortho-carboranylthio group at the meso(8)-position in BODIPYs $\mathbf{1 b}-\mathbf{3 b}, \mathbf{5 b}$, and $\mathbf{6 b}$ caused large red-shifts on the maximum absorption (up to $57 \mathrm{~nm}$ ) and emission (up to 73 $\mathrm{nm}$ ) bands. This is probably due to the stabilization of the LUMO by this group, which decreases the HOMO-LUMO gap. ${ }^{34}$ On the other hand, introduction of the same group at the $\alpha(5)$-position, as in BODIPY 7, induced a slight blue-shift $(\sim 5 \mathrm{~nm})$ relative to the starting BODIPY 6a. ${ }^{27}$ Arylation at the 8-position, as in BODIPY 4, also produced a slight 
blue-shift compared with the starting 8-chloro-BODIPY 1a probably due to a large dihedral angle between the aryl group and the BODIPY core. The fluorescence quantum yields were higher for BODIPY $\mathbf{1 b}$, suggesting low rotational freedom for the 8-carboranylthio group, and it decreased with increasing alkyl substitution for $\mathbf{2 b}, \mathbf{3} \mathbf{b}$, and $\mathbf{5 b}$. This is attributed to increased energy lost to nonradiative deactivation processes. ${ }^{27,34}$ On the other hand, BODIPY $\mathbf{4}$ shows much lower quantum yield than $\mathbf{7}$, probably due to the higher rotation of the 8-aryl group in the absence of 1,7-methyl groups.

\section{Cytotoxicity and Uptake in T98G Cells}

The cytotoxicity (dark and light, using $1.5 \mathrm{~J} / \mathrm{cm}^{2}$ light dose) and time-dependent uptake of all carboranyl-BODIPYs were investigated in human glioma T98G cells, and the results are summarized in Table 2 and Figure 2 (see also Figures S25 and S26 in the Supporting Information). The $\mathrm{IC}_{50}$ values were calculated from dose-response curves. This is the first report on the cytotoxicity and cellular uptake of carborane-containing BODIPYs.

None of the BODIPYs, with the exception of $\mathbf{5 b}$, showed any toxicity in the dark at concentrations up to $100 \mu \mathrm{M}$, as shown in Supporting Information, Figure S25. Upon irradiation with light, some BODIPYs showed enhanced cytotoxicity (see Supporting Information Figure S26), namely, 5b with calculated $\mathrm{IC}_{50}=40 \mu \mathrm{M}$ and $\mathbf{3 b}$ with calculated $\mathrm{IC}_{50}=80 \mu \mathrm{M}$; for all other BODIPYs the $\mathrm{IC}_{50}$ values were above $98 \mu \mathrm{M}$. The higher phototoxicity observed for $\mathbf{5 b}$ might be a result of its higher uptake by T98G cells, as shown in Figure 2. Indeed, $\mathbf{5 b}$ accumulated the most within cells at all the time points investigated, while 7 accumulated the least, among this series of BODIPYs. The very low uptake observed for BODIPY $\mathbf{7}$ is probably due to its poor aqueous solubility. The lipophilic character of this series of BODIPYs was evaluated by determining their distribution between 1 -octanol and water, and the values obtained for the partition coefficients $(\log P)$ are given in Table 2. The extent of cellular uptake did not correlate with the hydrophobic character of the BODIPYs, which increased in the order $\mathbf{1 b}<\mathbf{2 b}<\mathbf{3 b}<\mathbf{5 b} \sim \mathbf{6} b<\mathbf{4} \ll \mathbf{7}$. With the exception of $\mathbf{7}$, all compounds were taken up rapidly in the first $2 \mathrm{~h}$ after which slower uptake was observed for all compounds except for $\mathbf{1 b}$ where a plateau was reached. After 24 $\mathrm{h}$, the amount of compound accumulated within cells varied considerably (Table 2); compound $\mathbf{5 b}$ showed the highest uptake, about 436 -fold higher than $\mathbf{7}$, followed by $\mathbf{6 b}$ (135-fold higher than 7), 4 (118-fold higher than 7), $2 \mathbf{b}$ (106-fold higher than 7), 1b (67-fold higher than 7), and $\mathbf{3 b}$ (33-fold higher than 7). These results indicate that among this series of compounds, BODIPY $\mathbf{5 b}$ could deliver the largest and therapeutic amount of boron within glioma cells, with very low dark toxicity.

To investigate the sites of subcellular localization of the carboranyl-BODIPYs, HEp2 rather than T98G cells were used for fluorescence microscopy, as the HEp2 cells facilitate imaging by nicely spreading on the surface of the six-well plate. The organelle-specific probes BODIPY Ceramide (Golgi), LysoSensor Green (lysosomes), MitoTracker Green (mitochondria), and ER Tracker Blue/White (endoplasmic reticulum) were used in the overlay experiments. The results are shown in Figures 3 and 4 for BODIPYs $\mathbf{1 b}$ and $\mathbf{5 b}$, respectively (see also Supporting Information, Figures S27-S31). All carboranyl-BODIPYs localized preferentially in the cell ER, as shown in Figures $3 \mathrm{~d}$ and $4 \mathrm{~d}$. In addition, the 
BODIPYs were also observed, but to a smaller extent, in the lysosomes, mitochondria, and Golgi apparatus. These results are in agreement with previous studies showing preferential ER-localization for BODIPY molecules.

\section{BBB Permeability}

The hCMEC/D3 cell line is a useful model for studies of BBB permeability because it retains many of the morphological and functional characteristics of human brain endothelial cells. ${ }^{17}{ }^{19},{ }^{33}$ We have recently used this model to investigate the BBB permeability of a series of carboranylporphyrins ${ }^{16}$ and BODIPYs. ${ }^{20}$ All compounds of these types tested to date showed low permeability values $\left(P_{\mathrm{e}}<3 \times 10^{-6} \mathrm{~cm} / \mathrm{s}\right)$ with exception of BODIPY $3 \mathbf{b b}^{20}$ which showed higher permeability $\left(P_{\mathrm{e}}=4 \times 10^{-5} \mathrm{~cm} / \mathrm{s}\right)$ than LY. This was attributed to its smaller MW and lower hydrophobic character among the compounds tested. In this study we evaluated a new series of derivatives of $\mathbf{3 b}(\mathrm{MW}=422, \log P=1.7)$, with $\mathrm{MW}$ and hydrophobic character in the ranges $366-527 \mathrm{Da}$ and 1.5-2.7, respectively, chosen to favor BBB and tumor cell permeability. For comparison purposes and for evaluation of the cell monolayer integrity, we also determined the BBB permeability for LY, a polar fluorescent molecule with MW in the same range (457.24 Da) as the BODIPYs. The results obtained are shown in Table 2. The $P_{\mathrm{e}}$ values could not be determined for $\mathbf{4}$ and $\mathbf{7}$, due to their poor solubility in buffer, which caused these compounds to precipitate. All carboranyl-BODIPYs tested showed higher BBB permeability compared with LY, a marker for low BBB permeability. Among this series of compounds, $\mathbf{1 b}$ showed the highest $P_{\mathrm{e}}$ value (7-fold higher than LY), maybe due to its lower MW (366 Da) and favorable hydrophobic character ( $\log P=1.50$ ), conferring it the highest solubility in buffer as well as lipophilicity. Compound $\mathbf{2 b}$, of similar MW (394 Da) and hydrophobicity ( $\log P=1.69$ ) to $\mathbf{1 b}$, showed the second highest $P_{\mathrm{e}}$ value. The other BODIPYs, including $\mathbf{3 b}$, with increased alkyl and/or aryl substitution, MW $>400 \mathrm{Da}$, and $\log P>1.7$, showed lower $P_{\mathrm{e}}$ values although still higher than that determined for LY. Compound $\mathbf{5 b}$ showed the lowest $P_{\mathrm{e}}$ value among this series of BODIPYs, slightly higher than LY, and therefore is considered to have low BBB permeability, although it was the most efficiently taken up by the T98 glioma cells (Figure 2). All other BODIPYs display BBB permeabilities higher than that reported for phenytoin, which has been used as a marker for medium BBB permeability. ${ }^{33,}, 35$ Among the new BODIPYs, $\mathbf{1 b}, \mathbf{2 b}$, and $\mathbf{6 b}$ showed higher permeability than $\mathbf{3 b},{ }^{20}$ which displays a slightly higher $P_{\mathrm{e}}$ value than phenytoin. These results show that both the MW and amphiphilicity of the BODIPYs influence their permeability across the BBB and that small amphiphilic carboranyl-BODIPYs of MW $<400 \mathrm{Da}$ and $\log P<1.7$, such as $\mathbf{1 b}$ and $\mathbf{2 b}$, are the most efficient at diffusing across the BBB by passive diffusion.

\section{CONCLUSIONS}

A series of seven amphiphilic carboranyl-BODIPYs with MW within the range 366-527 Da, including a previously reported BODIPY known to permeate across a BBB model, were synthesized in good yields from the corresponding chloro-BODIPYs by nucleophilic substitution. The structures of the BODIPYs were confirmed by NMR, HRMS and, in the cases of $\mathbf{2 b}$ and $\mathbf{5 b}$, by X-ray crystallography. The carboranyl-BODIPYs display intense absorption and emission bands in the visible region of the spectrum and quantum yields in 
dichloromethane in the range 0.6-0.03. All BODIPYs showed low dark toxicity $\left(\mathrm{IC}_{50}>100\right.$ $\mu \mathrm{M}$ ) in human glioma T98G cells, an important property of potential boron delivery agents because of the high boron concentration requirement in BNCT ( $>20 \mu \mathrm{g} / \mathrm{g}$ tumor). The BODIPYs also showed low phototoxicity $\left(\mathrm{IC}_{50}>80 \mu \mathrm{M}\right)$ with the exception of $\mathbf{5 b}\left(\mathrm{IC}_{50}=\right.$ $40 \mu \mathrm{M}$ ), probably as a result of its remarkably high uptake into T98G glioma cells. On the other hand, BODIPY $\mathbf{1 b}$ showed the largest permeability across the BBB model consisting of hCMEC/D3 cells. Our results show that the BODIPYs with MW $<400 \mathrm{Da}$ and $\log P<$ 1.7 are the most efficient at crossing the BBB model. The most hydrophobic compound 7 $(\log P=2.7)$ was poorly soluble in aqueous solutions, showed very low uptake into T98G cells, and its precipitation in buffer precluded determination of its BBB permeability. All BODIPYs tested showed higher BBB permeability compared with LY, as well as low dark cytoxicity and therefore could potentially be efficient boron delivery agents for BNCT of brain tumors. Among this series, $\mathbf{1 b}$ and $\mathbf{2 b}$ showed the highest BBB permeability while $\mathbf{5 b}$ and $\mathbf{6 b}$ accumulated the most within tumor cells; therefore, these are the most promising BNCT agents.

\section{Supplementary Material}

Refer to Web version on PubMed Central for supplementary material.

\section{Acknowledgments}

The authors are thankful to Dr. Pierre-Olivier Couraud from the Institut COCHIN (Paris, France) for providing the hCMEC/D3 cells. This work was supported by the National Institutes of Health, Grant R01 CA179902.

\section{ABBREVIATIONS USED}

$\begin{array}{ll}\text { BNCT } & \text { boron neutron capture therapy } \\ \text { BBB } & \text { blood-brain barrier } \\ \text { LET } & \text { linear energy transfer } \\ \text { PDT } & \text { photodynamic therapy } \\ \text { PBS } & \text { phosphate buffered saline } \\ \text { EBM-2 } & \text { endothelial cell basal medium 2 } \\ \text { bFGF } & \text { human basic fibroblast growth factor } \\ \text { FBS } & \text { fetal bovine serum } \\ \text { HEPES } & \text { 2-[4-(2-hydroxyethyl)-piperazin-1-yl]ethanesulfonic acid } \\ \text { HBSS } & \text { Hanks' balanced salt solution } \\ \text { TLC } & \text { thin layer chromatography } \\ \text { HPLC } & \text { high performance liquid chromatography } \\ \text { ER } & \text { endoplasmic reticulum }\end{array}$




\section{References}

1. Soloway AH, Tjarks W, Barnum BA, Rong FG, Barth RF, Codogni IM, Wilson JG. The Chemistry of Neutron Capture Therapy. Chem Rev. 1998; 98:1515-1562. [PubMed: 11848941]

2. Barth RF, Coderre JA, Vicente MGH, Blue TE. Boron Neutron Capture Therapy of Cancer: Current Status and Future Prospects. Clin Cancer Res. 2005; 11:3987. [PubMed: 15930333]

3. Barth RF, Vicente MGH, Harling O, Kiger W, Riley K, Binns P, Wagner F, Suzuki M, Aihara T, Kato I, Kawabata S. Current Status of Boron Neutron Capture Therapy of High Grade Gliomas and Recurrent Head and Neck Cancer. Radiat Oncol. 2012; 7:146-167. [PubMed: 22929110]

4. Kankaanranta L, Seppälä T, Koivunoro H, Saarilahti K, Atula T, Collan J, Salli E, Kortesniemi M, Uusi-Simola J, Välimäki P, Mäkitie A, Seppänen M, Minn H, Revitzer H, Kouri M, Kotiluoto P, Seren T, Auterinen I, Savolainen S, Joensuu H. Boron Neutron Capture Therapy in the Treatment of Locally Recurred Head-and-Neck Cancer: Final Analysis of a Phase I/II Trial. Int J Radiat Oncol, Biol Phys. 2012; 82:e67-e75. [PubMed: 21300462]

5. Hopewell JW, Gorlia T, Pellettieri L, Giusti V, H-Stenstam B, Sköld K. Boron Neutron Capture Therapy for Newly Diagnosed Glioblastoma Multiforme: An Assessment of Clinical Potential. Appl Radiat Isot. 2011; 69:1737-1740. [PubMed: 21482122]

6. Pardridge W. The Blood-Brain Barrier: Bottleneck in Brain Drug Development. NeuroRx. 2005; 2:3-14. [PubMed: 15717053]

7. Sibrian-Vazquez, M.; Vicente, MGH. Boron Tumor-Delivery for BNCT: Recent Developments and Perspectives. In: Hosmane, NS., editor. Boron Science: New Technologies and Applications. CRC Press; 2011. p. 203-232.

8. Deeken JF, Löscher W. The Blood-Brain Barrier and Cancer: Transporters, Treatment, and Trojan Horses. Clin Cancer Res. 2007; 13:1663-1674. [PubMed: 17363519]

9. Provenzale JM, Mukundan S, Dewhirst M. The Role of Blood-Brain Barrier Permeability in Brain Tumor Imaging and Therapeutics. AJR, Am J Roentgenol. 2005; 185:763-767. [PubMed: 16120931]

10. Roda E, Nion S, Bernocchi G, Coccini T. Blood-Brain Barrier (BBB) Toxicity and Permeability Assessment after L-(4-boronophenyl)alanine, a Conventional B-containing Drug for Boron Neutron Capture Therapy, Using an in vitro BBB Model. Brain Res. 2014; 1583:34-44. [PubMed: 25128598]

11. Sivaev IB, Bregadze VV. Polyhedral Boranes for Medical Applications: Current Status and Perspectives. Eur J Inorg Chem. 2009; 2009:1433-1450.

12. De Vries HE, Kuiper J, De Boer AG, Van Berkel TJ, Breimer DD. The Blood-Brain Barrier in Neuroinflammatory Diseases. Pharmacol Rev. 1997; 49:143-155. [PubMed: 9228664]

13. Palmer AM, Alavijeh MS. Foundation Review: Translational CNS Medicines Research. Drug Discovery Today. 2012; 17:1068-1078. [PubMed: 22580061]

14. Habgood MD, Begley DJ, Abbott NJ. Determinants of Passive Drug Entry into the Central Nervous System. Cell Mol Neurobiol. 2000; 20:231-253. [PubMed: 10696512]

15. Coderre JA, Turcotte JC, Riley KJ, Binns PJ, Harling OK, Kiger WS. Boron Neutron Capture Therapy: Cellular Targeting of High Linear Energy Transfer Radiation. Technol Cancer Res Treat. 2003; 2:355-375. [PubMed: 14529302]

16. Bhupathiraju NVSDK, Hu X, Zhou Z, Fronczek FR, Couraud PO, Romero IA, Weksler B, Vicente MGH. Synthesis and in vitro Evaluation of BBB Permeability Tumor Cell Uptake and Cytotoxicity of a Series of Carboranylporphyrin Conjugates. J Med Chem. 2014; 57:6718-6728. [PubMed: 25029034]

17. Weksler BB, Subileau EA, Perrière N, Charneau P, Holloway K, Leveque M, Tricoire-Leignel H, Nicotra A, Bourdoulous S, Turowski P, Male DK, Roux F, Greenwood J, Romero IA, Couraud PO. Blood-Brain Barrier-Specific Properties of a Human Adult Brain Endothelial Cell Line. FASEB J. 2005; 19:1872-1874. [PubMed: 16141364]

18. Poller B, Gutmann H, Krähenbühl S, Weksler B, Romero I, Couraud PO, Tuffin G, Drewe J, Huwyler J. The Human Brain Endothelial Cell Line hCMEC/D3 as a Human Blood-Brain Barrier Model for Drug Transport Studies. J Neurochem. 2008; 107:1358-1368. [PubMed: 19013850] 
19. Weksler B, Romero IA, Couraud PO. The hCMEC/D3 Cell Line as a Model of the Human Blood Brain Barrier. Fluids Barriers CNS. 2013; 10:16-25. [PubMed: 23531482]

20. Gibbs JH, Wang H, Bhupathiraju NVSDK, Fronczek FR, Smith KM, Vicente MGH. Synthesis and Properties of a Series of Carboranyl-BODIPYs. J Organomet Chem. 2015; 798:209-213. [PubMed: 26688595]

21. Loudet A, Burgess K. BODIPY Dyes and Their Derivatives: Syntheses and Spectroscopic Properties. Chem Rev. 2007; 107:4891-4932. [PubMed: 17924696]

22. Boens N, Leen V, Dehaen W. Fluorescent Indicators Based on BODIPY. Chem Soc Rev. 2012; 41:1130. [PubMed: 21796324]

23. Lu H, Mack J, Yang Y, Shen Z. Structural Modification Strategies for the Rational Design of Red/NIR Region BODIPYs. Chem Soc Rev. 2014; 43:4778-4823. [PubMed: 24733589]

24. Kowada T, Maeda H, Kikuchi K. BODIPY-based Probes for the Fluorescence Imaging of Biomolecules in Living Cells. Chem Soc Rev. 2015; 44:4953. [PubMed: 25801415]

25. Godoy J, Vives G, Tour JM. Synthesis of Highly Fluorescent BODIPY-based Nanocars. Org Lett. 2010; 12:1464-1467. [PubMed: 20210334]

26. Wang H, Vicente MGH, Fronczek FR, Smith KM. Synthesis and Transformations of 5-Chloro-2,2Dipyrrins and Their Boron Complexes, 8-Chloro-BODIPYs. Chem - Eur J. 2014; 20:5064-5074. [PubMed: 24616111]

27. Zhao N, Vicente MGH, Fronczek FR, Smith KM. Synthesis of 3,8-Dichloro-6-ethyl-1,2,5,7tetramethyl-BODIPY from an Asymmetric Dipyrroketone and Reactivity Studies at the 3,5,8Positions. Chem - Eur J. 2015; 21:6181-6192. [PubMed: 25761150]

28. Hao E, Fabre B, Fronczek FR, Vicente MGH. Syntheses and Electropolymerization of CarboranylFunctionalized Pyrroles and Thiophenes. Chem Mater. 2007; 19:6195-6205.

29. Leen V, Yuan P, Wang L, Boens N, Dehaen W. Synthesis of Meso-Halogenated BODIPYs and Access to Meso-Substituted Analogues. Org Lett. 2012; 14:6150-6153. [PubMed: 23214969]

30. Lakowicz, JR. Principles of Fluorescence Spectroscopy. 3. Springer; New York: 2006.

31. Kraszni M, Bányai I, Noszál B. Determination of Conformer-Specific Partition Coefficients in Octanol/Water Systems. J Med Chem. 2003; 46:2241-2245. [PubMed: 12747795]

32. Siflinger-Birnboim A, del Vecchio PJ, Cooper JA, Blumenstock FA, Shepard JM, Malik AB. Molecular Sieving Characteristics of the Cultured Endothelial Monolayer. J Cell Physiol. 1987; 132:111-117. [PubMed: 3597548]

33. Cucullo L, Couraud PO, Weksler B, Romero IA, Hossain M, Rapp E, Janigro D. Immortalized Human Brain Endothelial Cells and Flow-based Vascular Modeling: a Marriage of Convenience for Rational Neurovascular Studies. J Cereb Blood Flow Metab. 2008; 28:312-328. [PubMed: 17609686]

34. Boens N, Wang L, Leen V, Yuan P, Verbelen B, Dehaen W, Van der Auweraer M, De Borggraeve WD, Van Meervelt L, Jacobs J, Beljonne D, Tonnel C, Lazzaroni R, Ruedas-Rama MJ, Orte A, Crovetto L, Talavera EM, Alvarez-Pez JM. 8-HaloBODIPYs and Their 8-(C, N, O, S) Substituted Analogues: Solvent Dependent UV-Vis Spectroscopy, Variable Temperature NMR, Crystal Structure Determination, and Quantum Chemical Calculations. J Phys Chem A. 2014; 118:15761594. [PubMed: 24552403]

35. Martinez CHR, Miller F, Ganeshamoorthy K, Glacial F, Kaiser M, De Koning HP, Eze AA, Lagartera L, Herraiz T, Dardonville C. A New Nonpolar $N$-Hydroxy Imidazoline Lead Compound with Improved Activity in a Murine Model of Late-Stage Trypanosoma brucei brucei Infection is not Cross-Resistant with Diamidines. Antimicrob Agents Chemother. 2015; 59:890-904.

[PubMed: 25421467] 

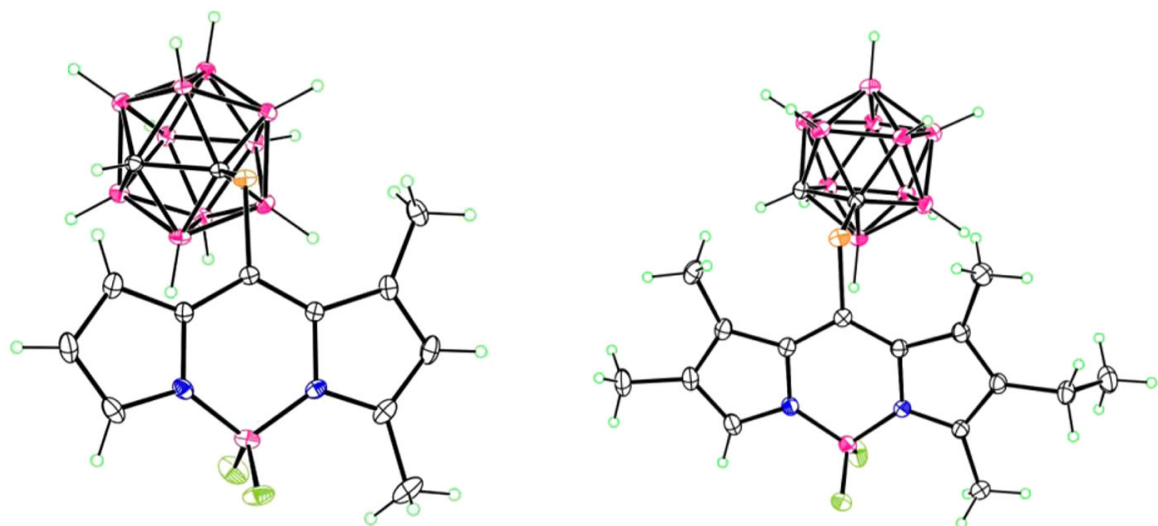

Figure 1.

X-ray crystal structures of $\mathbf{2 b}$ (left) and $\mathbf{5 b}$ (right).

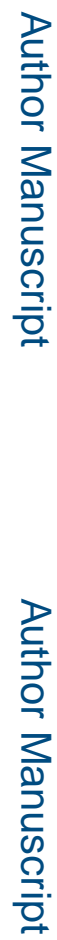




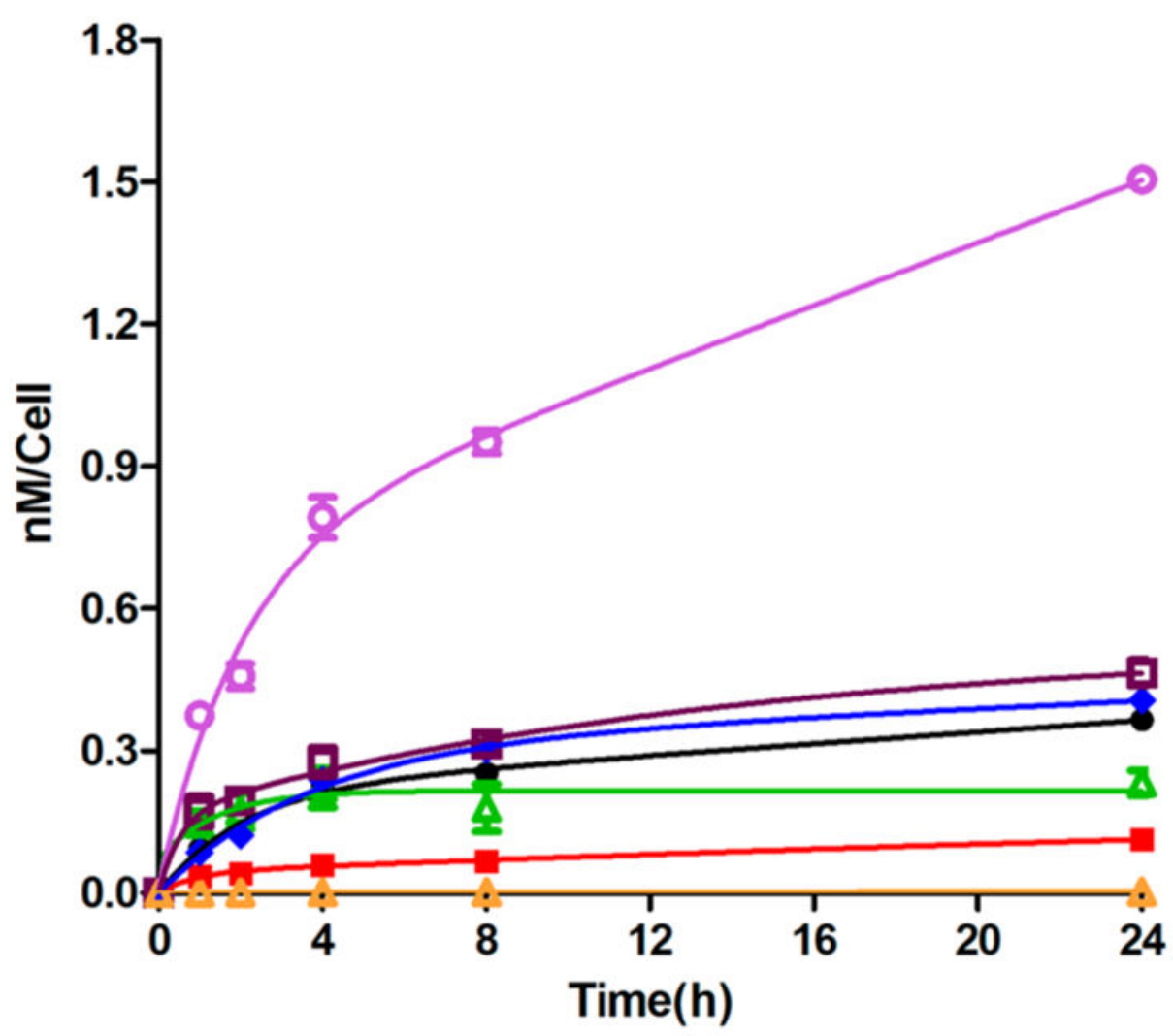

Figure 2.

Time-dependent uptake of BODIPYs $\mathbf{1 b}$ (green), 2b (black), $\mathbf{3 b}$ (red), $\mathbf{4}$ (blue), $\mathbf{5 b}$ (purple), 6b (dark red), and 7 (orange) at $10 \mu \mathrm{M}$ in human glioma T98G cells. 


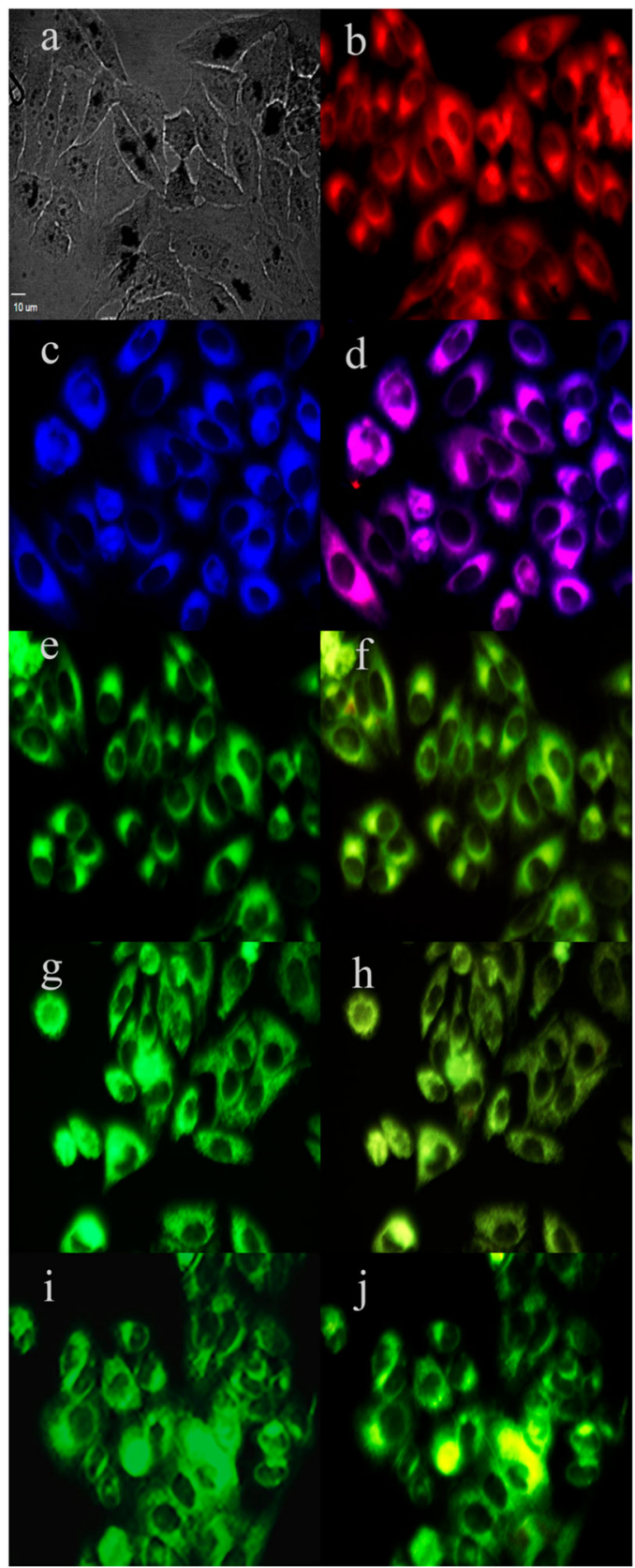

Figure 3.

Subcellular localization of $\mathbf{1 b}$ in HEp2 cells at $10 \mu \mathrm{M}$ for $6 \mathrm{~h}$ : (a) phase contrast, (b) overlay of $\mathbf{1 b}$ and phase contrast, (c) ER Tracker Blue/White, (d) overlay of $\mathbf{1 b}$ and ER Tracker, (e) BODIPY ceramide, (f) overlay of $\mathbf{1 b}$ and BODIPY ceramide, (g) MitoTracker Green, (h) overlay of $\mathbf{1 b}$ and MitoTracker, (i) LysoSensor Green, (j) overlay of $\mathbf{1 b}$ and LysoSensor. Scale bar: $10 \mu \mathrm{m}$. 


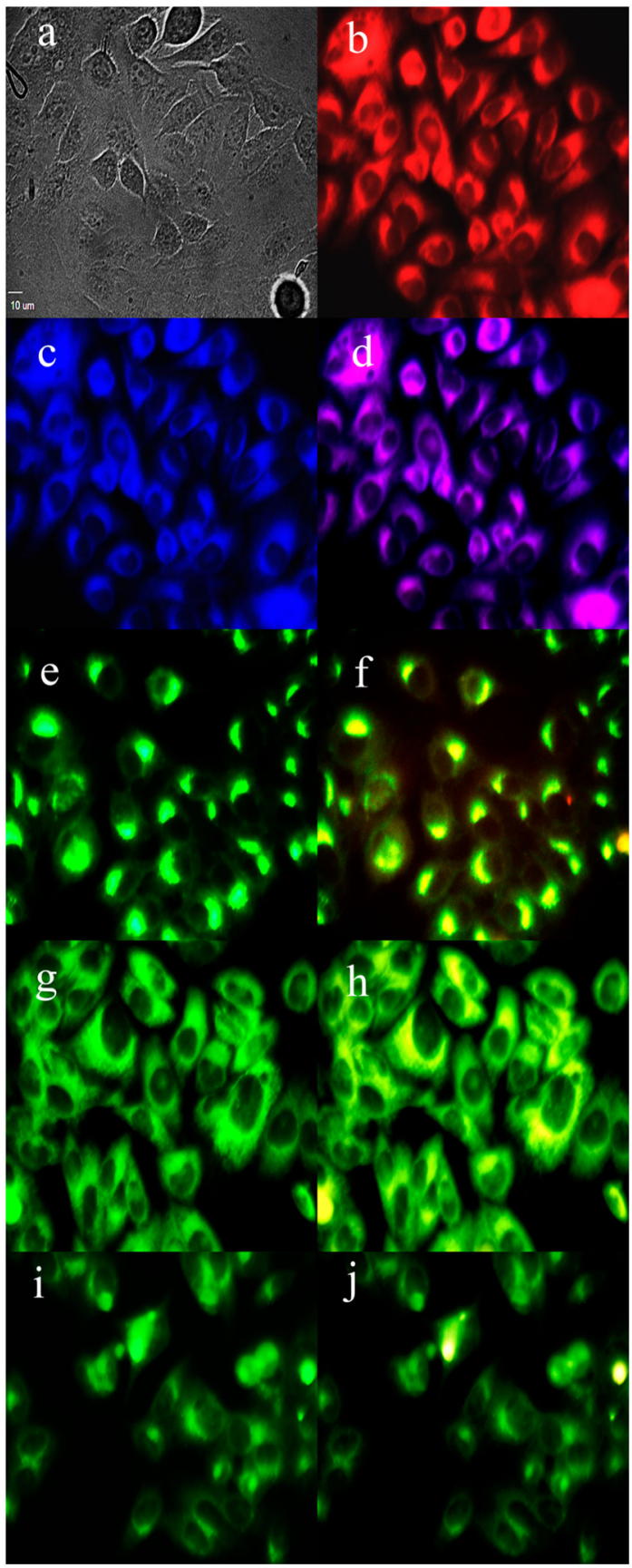

Figure 4.

Subcellular localization of $\mathbf{5 b}$ in HEp2 cells at $10 \mu \mathrm{M}$ for $6 \mathrm{~h}$ : (a) phase contrast, (b) overlay of $\mathbf{5 b}$ and phase contrast, (c) ER Tracker Blue/White, (d) overlay of $\mathbf{5 b}$ and ER Tracker, (e) BODIPY ceramide, (f) overlay of $\mathbf{5 b}$ and BODIPY ceramide, (g) MitoTracker Green, (h) overlay of $\mathbf{5 b}$ and MitoTracker, (i) LysoSensor Green, (j) overlay of $\mathbf{5 b}$ and LysoSensor. Scale bar: $10 \mu \mathrm{m}$. 


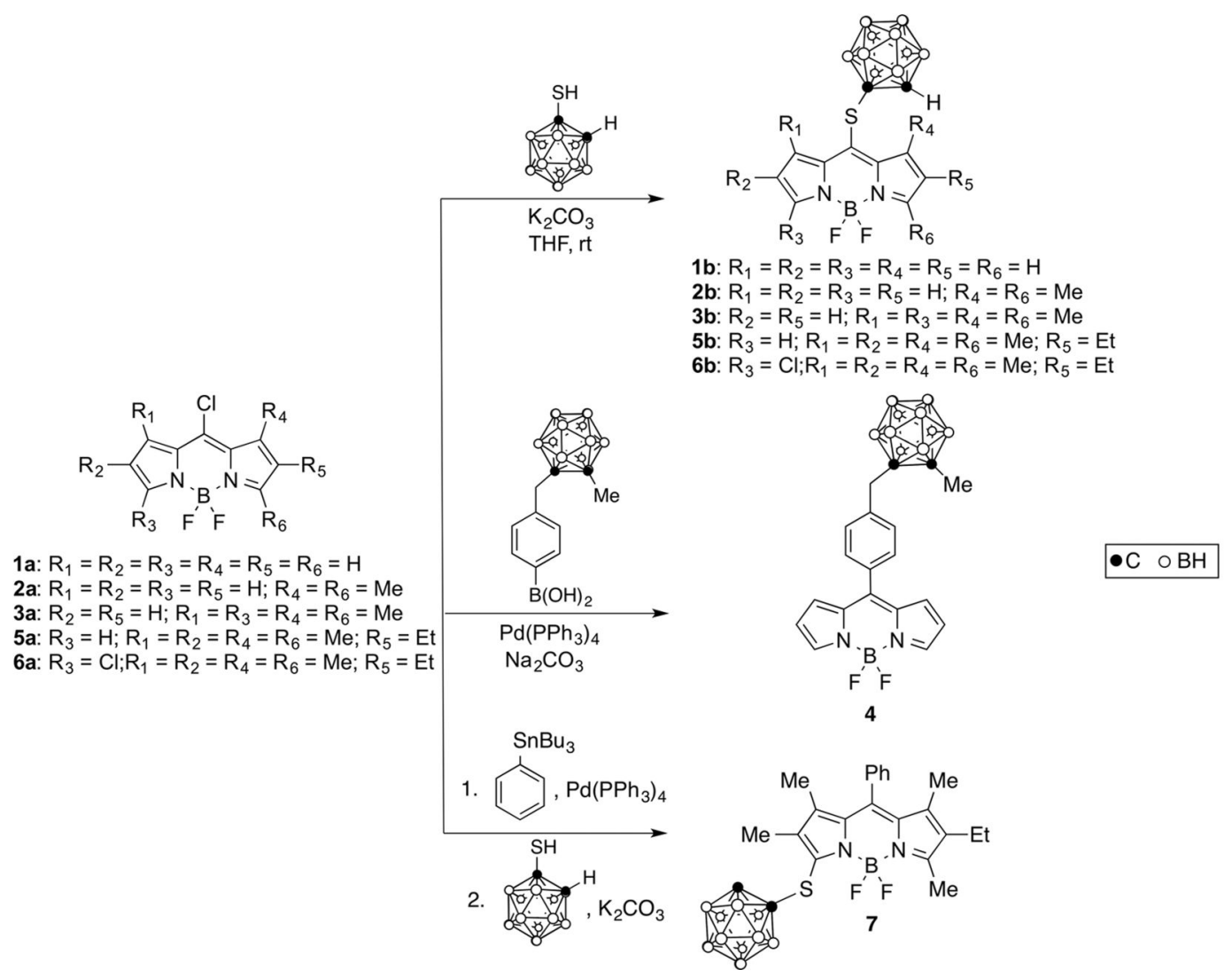

Scheme 1. 


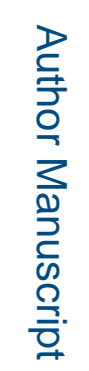

로을

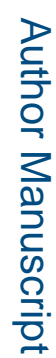

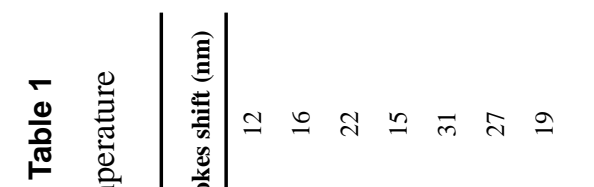

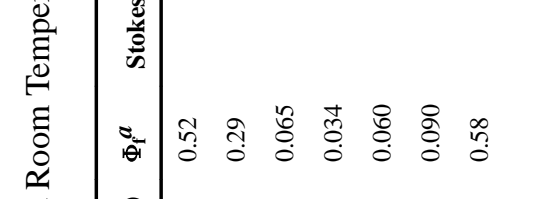

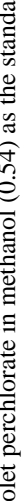

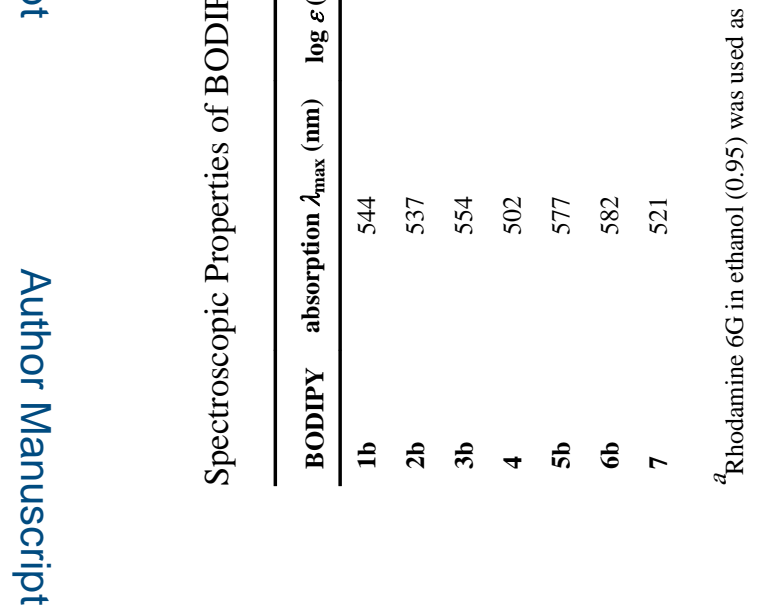

点 会

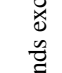

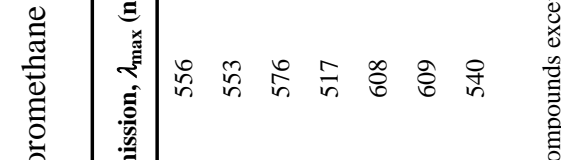

JMed Chem. Author manuscript; available in PMC 2016 June 06. 


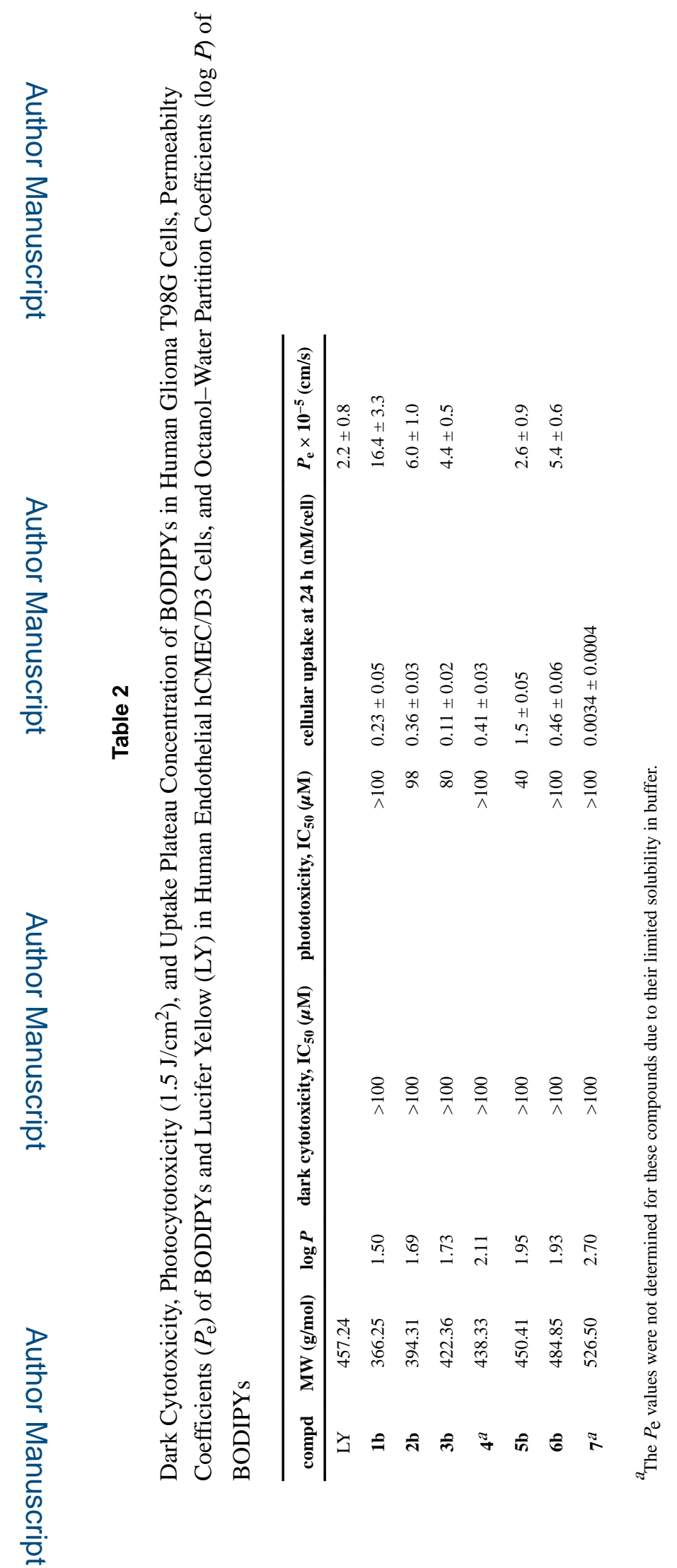

JMed Chem. Author manuscript; available in PMC 2016 June 06. 